\title{
South Africa: Who uses youth centers and why?
}

Frontiers in Reproductive Health

Follow this and additional works at: https://knowledgecommons.popcouncil.org/departments_sbsr-rh

Part of the Counseling Commons, Demography, Population, and Ecology Commons, Family, Life Course, and Society Commons, International Public Health Commons, and the Vocational Education Commons How does access to this work benefit you? Let us know!

\section{Recommended Citation}

"South Africa: Who uses youth centers and why?" FRONTIERS OR Summary. Washington, DC: Population Council, 2001. 


\section{South Africa Youth OR Summary 23}

\title{
Who Uses Youth Centers and Why?
}

\begin{abstract}
Less than one-third of local youth have ever visited the youth centers in this study area of South Africa. More than half of the youth center visitors were sexually experienced, but visiting a center had little discernible effect on reproductive health knowledge or safer sexual behavior. Youth want friendly, non-judgmental providers. Youth-only facilities and young providers are less important to them.
\end{abstract}

\section{Background}

In 2000, the Reproductive Health Research Unit in KwaZulu Natal and Population Council conducted an assessment of 12 youth centers and seven affiliated peer education programs. The 12 centers, located in urban, peri-urban, and rural areas, offer very different services. The two centers of the KwaZulu-Natal (KZN) Department of Health focus on providing reproductive health (RH) information and services to adolescents. The six centers of the Youth and Adolescent Reproductive Health Project (YARHP) provide a broader range of youth-friendly $\mathrm{RH}$ services, including counseling and life skills education, as well as modest recreational activities. The four centers run by loveLife have large multi-purpose facilities with a wide range of recreational activities, vocational and life skills training, and RH services.

Data sources for the study were: an inventory of youth center services; interviews with center staff and clients; financial and administrative records; and community surveys of 1,399 young people aged 12-24 and their parents. The surveys were taken from a catchment area of up to three kilometers from each center.

\section{Findings}

- Sixty-one percent of youth within the catchment areas knew of the centers, and 29 percent reported that they use the centers' services. Since these centers probably reach even fewer youth living further away, this finding suggests that youth centers alone are unlikely to meet the reproductive health needs of most African youth, particularly in rural areas, given present resource constraints.

- The services that youth received from youth centers mostly reflected the services they offer (see Figure). Most youth came to the KZN Department of Health and YARHP youth centers for RH clinical services, which is their focus. In contrast, most youth visiting loveLife centers came for recreation, followed by RH services and life skills training. Youth sought clinical services

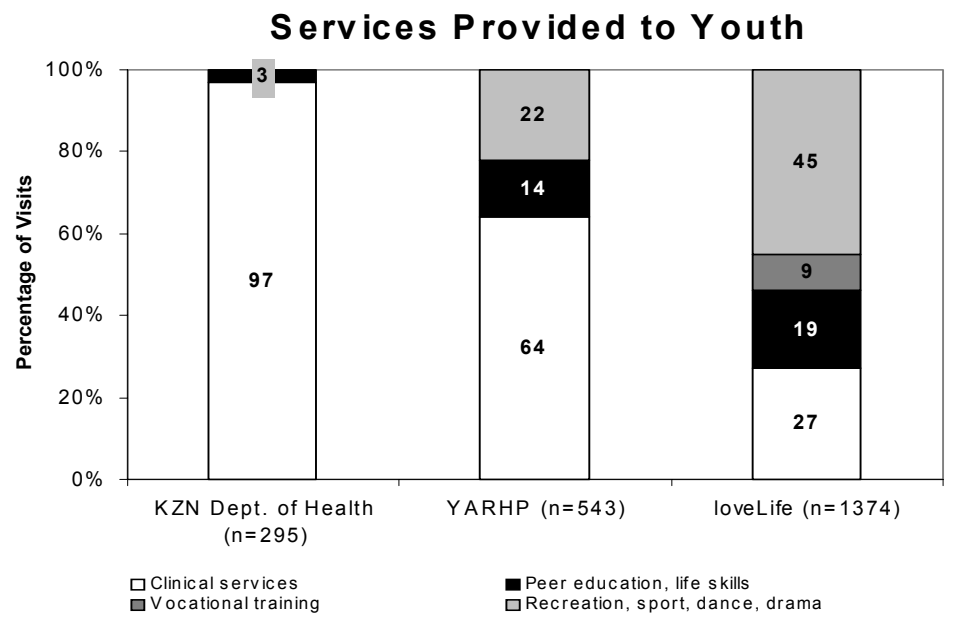

Source: Clinic sign-in register 
more often than peer education, life skills training, and reproductive health information. Vocational training activities reached relatively few young people.

- More than half of the youth center visitors were sexually experienced, and thus are a priority audience for RH programs. However, there was little discernible difference between center users and non-users in terms of RH knowledge and safer sexual behavior. Boys who had visited a youth center in the previous three months were more likely to have initiated sex earlier than non-visitors, but there was no difference among girls. Condom use was similar among center visitors and non-visitors.

- Three in five youth had heard of the youth centers, mainly from friends. Outreach activities by staff and peer educators did not draw many youth to the centers. The major reasons youth gave for not visiting the centers were lack of time, inadequate information about the center, and the travel distance. Inconvenient hours may be another factor; one in five youth said they had gone to a center but found it closed.

- Young people stated that the most important aspects of RH services were having a friendly staff, a short waiting time, an unhurried consultation with a service provider, comprehensive services, nonjudgmental staff, low-cost or free services, and convenient hours and location. Factors such as attending a youth-only facility and having a young service provider were less important to them. Though nearly all young people found the staff friendly, three in four said they would prefer service from a peer educator older than themselves.
- Boys tended to visit the centers for recreation, while girls came for RH services, especially contraception. Recreational facilities attracted younger visitors, especially those aged 15-18, while those aged 19 and older were more likely to seek RH services. Many female clients — over half in three of the centers - were older than the centers' target age range.

- Peer educators had highly variable performance. Half dropped out of the program within a year of training. Nevertheless, most young people had positive experiences with peer educators. Peer educators in five centers reported that they had had contact with at least 20 young people in the previous week, mostly in a group setting.

- Key topics for health education are the need for dual protection against both pregnancy and sexually transmitted infections, including HIV/AIDS, and prevention of sexual violence.

\section{Policy Implications}

- To help develop programs for youth, managers should develop strong systems to monitor use and to identify and meet users' needs. As demand for RH services seems to be increasing among older adolescents, centers might consider reviewing their target range.

- Program managers need to define the reproductive health benefits expected as a result of community interventions to reach youth.

Erulkar, Annabel S., Mags Beksinka, and Queen Cebekhulu. 2001. An Assessment of Youth Centres in South Africa. Nairobi: Population Council. For more information, contact: Population Council, P.O. Box 17643, Nairobi, Kenya. Tel. 254-2-713-480; Fax 254-2-713-479; Email:publications@popcouncil.or.ke.

This project was conducted with support from the U.S. AGENCY FOR INTERNATIONAL DEVELOPMENT under Cooperative Agreement Number HRN-A-00-98-00012-00. 